\title{
II
}

\section{LA HORA DE LAS AMERICAS}

Quienes han estudiado a conciencia la historia de América notan que en ella sus grandes crisis corresponden a crisis semejantes en la historia europea. Asi, la revolución francesa, al repercutir en el Nuevo Mundo, trajo como resultado su independencia política, y la guerra mundial, su parcial independencia económica. ¿Cuál será para él la consecuencia mediata o inmediata del conflicto que amenaza la existencia misma de Europa? ¿Será su completa independencia económica, y la cultural?

De Europa ha recibido América cuanto en ella constituye una promesa genuina $\mathrm{y}$ un positivo valor: sangre, idioma, religión, ciencia, arte, comercio, industria, normas sociales, derroteros políticos, anhelos trascendentes, inspiraciones supremas. Desde los días ya lejanos del Descubrimiento, el Viejo Mundo ha venido echando sobre el Nuevo la simiente de una vida mejor y el afán profundo e irresistible de expresarla en formas propias... Mas ahora Europa parece estar en vía de desintegrarse, y se halla consagrada casi por entero a defenderse de los males que en su seno han desatado todas las concupiscencias del mundo y de la carne. Allá peligra la labor de los siglos, fracasan los principios y los ideales más caros al hombre, se entronizan los bajos instintos, se desenmasca- 
ran las "ideologías" y el odio y la desconfianza se apoderan de los pueblos y los conducen a la violencia y el exterminio. ¿Quiénes habrán de recoger el tesoro de la cultura occidental para salvarlo y glorificarlo? ¿Quiénes ha* brán de levantar, más en alto que nunca, las banderas de la justicia, la caridad, el bien, la libertad, la belleza, la dignidad personal, la confraternidad universal y la verdad puesta al servicio de la vida y del espiritu?

¡La Hora de América ha llegado!

Hasta el presente, los valores que de Europa nos venían brillaban para nosotros con la gloria de lo alto y trascendente. $Y$ dirigíamos hacia ella nuestra mirada ansiosamente, en espera de sus designios, sus hallazgos, sus gestos, sus creaciones... De Europa dependíamos culturalmente. Aun nuestros hombres eximios se preocupaban más de la vida europea que de la americana, y a Europa acudian aún en busca de apetecidas consagraciones... ¿Podemos seguir así y aceptar al mismo tiempo las grandes responsabilidades que la hora nos pone en las manos inexpertas todavia?

América no puede permanecer indiferente, ni tampoco sumisa y apocada. América tiene que afirmar serena y audazmente su propio anhelo de ser, y mantener a toda costa su fe en el Ideal, y buscar su realización victoriosa en el esfuerzo colectivo, unánime, firme, sostenido, disciplinado, serio y claramente orientado. Los americanos del norte, del centro y del sur sabemos ya distinguir el bien del mal, la belleza de la fealdad, y la verdad de la mentira, y nos damos cuenta cabal del significado redentor de los ensueños e ideales que encarnaron en las personas de nuestros libertadores y de nuestros guías más excelsos, Bolivar, Washington, San Martin, y Hamilton, Jefferson, Martí y Sarmiento, y Bello, Darío, Mariátegui y Rodó... Ideales de paz y de justicia, de verdad y de 
r4 REVISTA IBEROAMERTCA NA

belleza, de dignidad y de armonia, que fueron generosa acción constructiva - llama y luz- en nuestros hombres de ayer y que serán aliento y fuerza -ala y fuego- en los hombres de mañana, si es que la América ha de aceptar su augusto destino singular: realizar para siempre el ensueño de las edades y hacer posible el reino del Espíritu entre los pueblos. 